\title{
ENTREPRENEURSHIP AMONG THE DISPLACED AND DISPOSSESSED: EXPLORING THE LIMITS OF EMANCIPATORY ENTREPRENEURING
}

\begin{abstract}
This paper explores the links between entrepreneurship, emancipation and gender within the international development arena. Through a longitudinal analysis of a micro-enterprise development project in which intermediary organizations contract traditional handicrafts from female home-based producers, we focus on the impact of contracting policies on the ability of the desperately poor to improve their disadvantaged position. Our critical analysis reveals how intermediaries who impose exclusive contracting conditions, supposedly to protect the women's interests, actually constrain the emancipatory potential of the women's entrepreneurial activities. However, such contractual limitations generate collaborative networks enabling the women to challenge these constraints in an effort to assert control over their activities. Accordingly, this paper contributes to contemporary debates concerning the emancipatory potential of entrepreneurship within the context of development. We advance this analysis through a gendered evaluation of the role of intermediary organizations upon entrepreneurial emancipation and related empowerment.
\end{abstract}

\section{KEY WORDS}

International development, emancipatory entrepreneuring, intermediary organizations, gender 


\section{INTRODUCTION}

Entrepreneurship is both an economic and a social phenomenon (Steyaert and Katz, 2004) whose manifestation varies according to context (Zahra et al, 2014). Affording greater attention to context has revealed a mature economy bias within normative entrepreneurial theorising (Bruton et al, 2008) prompting calls for a more inclusive approach recognising, for example, the entrepreneurial activities of the desperately poor in the underdeveloped 'bottom of the pyramid' regions of the global south (Ansari et al, 2012). Broadening and contextualising the current research agenda enables a more nuanced and theoretically challenging view of the potential for entrepreneurship to act as a development tool with emancipatory scope.

Notions of emancipation are central to Rindova et al's (2009) thesis whereby entrepreneuring, as an active 'doing', has the potential to effect socio-economic change in contexts where poverty and marginalisation constrain resources and opportunities. This emergent strand of theorising resonates with international development studies where a desire for social change and associated human emancipation are central to debates (Sen, 1985; 1999). Encouraged by supra-governmental institutions such as the World Bank and major donor agencies, governments in developing countries have focused upon the potential value of entrepreneurship as a strategy for economic and social development. Realising this strategy however, requires the presence of intermediaries, such as Non-Governmental Organizations (NGOs), social enterprises and commercial contractors. Such intermediaries stimulate and support the development of entrepreneurial capabilities when acting as product distribution agents on the behalf of local entrepreneurs (Al-Dajani and Marlow, 2013; Mair et al, 2012; Khavul et al, 2013). As such, they have a crucial role enhancing or constraining emancipatory potential depending upon the nature of their engagement with local producers. 
Within this paper, we adopt the novel stance of exploring the impact of contracting policies used by intermediary organizations on the ability of the desperately poor to improve their disadvantaged position. In so doing, we contribute to the emerging development, entrepreneurship and emancipation literature when examining the complex relationship between intermediary organizations and self-employed local producers. Additionally, we adopt a gendered perspective by focusing specifically upon women engaged in home-based self-employment.

Since the early 1990s, a growing body of literature has explored the influence of gendered ascriptions upon women's entrepreneurial activities revealing how a masculine bias shapes the assumptions underpinning entrepreneurship and positions women in deficit (Ahl, 2006; Ahl and Marlow, 2012; Marlow, 2014). This well-rehearsed and multi-faceted argument has been expounded by a range of critical reviews, conceptual analyses and related empirical illustrations (Marlow, 2014; Ahl, 2006; Carter and Shaw, 2006; Calás et al, 2009; Hughes et al, 2012). Although the extant literature adopts differing perspectives and approaches, the overwhelming consensus is that the ontological foundations of entrepreneurship presume a normative masculinity (Bruni et al., 2004; Bruni and Poggio, 2005). This debate has been transformatory - revealing tensions between the assumptions underpinning entrepreneurship as an agentic, meritocratic field and the realities of everyday entrepreneuring bounded by ascribed social norms and constraints (Mole and Ram, 2012). However, this debate has tended to reproduce the partiality of mainstream entrepreneurship (Bruton et al., 2008) through an uncritical assumption of the developed economy as a normative template for the enactment of gendered practices (Al-Dajani and Marlow, 2013). 
To challenge such gendered and contextual biases, we explore the enterprising activities of displaced Palestinian women in East Amman, Jordan who suffer from a matrix of disadvantages given their poverty, displacement and subordinated gendered status. One of the few available pathways for their socio-economic participation is self-employed home-based production of traditional craft products; this micro-enterprise combination of domestic production and a traditional feminised activity is deemed acceptable within the prevailing culture of patriarchal social norms. Micro-enterprise of this type only becomes viable through intermediary organizations performing dual roles as patron-donors and client-contractors, casting individual producers both as aid beneficiaries and low cost suppliers. Accordingly, within this paper we explore the extent to which these intermediary organizations enable or constrain desperately poor women to access the emancipatory potential of home-based entrepreneurship.

We use the interface between entrepreneurship, gender and development to frame our empirical analysis of the role of intermediary organizations as brokers in this relationship. While their remit is to enable and encourage entrepreneurial activity, this is impeded by the restrictive contractual arrangements which they impose. This reveals a paradoxical tension whereby the emancipatory potential of entrepreneurship is thwarted by those seeking to enable it. Revealing this contradictory tension informs the underpinning research objective of this paper which centres upon an empirically informed examination of the role of intermediary organizations in enhancing the potential emancipation prospects of desperately poor women through micro-entrepreneuring activities. To explore these arguments, this paper is structured as follows: the first section outlines our literature analysis framing the paper; second, we describe our methodology and approach; third, there is an overview and 
discussion of empirical findings and finally we conclude by outlining our contribution to debate, limitations of the study and suggestions for future research.

\section{Capabilities, Empowerment and Emancipatory Entrepreneuring}

Sen's (1999) classic text 'Development as Freedom' prompted a radical shift in sustainable poverty alleviation approaches in international development. By arguing that individual and community development require a range of mechanisms that progressively enable a range of freedoms, Sen popularised debates familiar to development practitioners. These ranged from earlier work documenting the Capabilities Approach (CA) (Dreze and Sen, 1989; Sen, 1985) and alternative models including the Basic Needs Approach (BNA) and the Empowerment Approach. Sen (1999) rejected the notion that wellbeing can be reduced to real income levels, arguing that individual capabilities (the ability to achieve) and functionings (achievements) were a more appropriate focus. While functionings refer to 'what an individual may value doing or being, ranging from elementary aspects, such as being adequately nourished to complex issues, such as having self-respect' (Ansari et al, 2012:819), capabilities are the ability to achieve functioning. Sen (1999) argued that human wellbeing requires an expansion of both functionings (achievements) and capabilities to realise these possibilities. Variations in individual capability sets and the range of attainable functionings a person can achieve lie at the crux of Sen's (1999) thesis, which "challenges us to reshape the problem of poverty from 'a failure to reach some absolute level of capability' into 'the issue of inequality of capabilities"” (Ansari et al, 2012: 820).

The Capabilities Approach (Sen; 1985, 1999) resonates with a parallel stream of work within international development programming focusing upon women's empowerment. Women experiencing extreme poverty have been a focal point of attention within international 
development given their multiple disadvantages alongside their critically important role in managing family resources and child care (Al-Dajani, 2007). This gendered stream of international development programming has its origins in the 1950s Welfare Approach; this assumed that the benefits of economic development would trickle down from male heads of households to women benefitting the family and community (Oxaal and Baden, 1997). The fundamentally patriarchal assumptions underpinning this approach were subject to criticism and revision evolving to encompass the Economic Self Reliance Approach (1960s), the Efficiency Approach (1970s) and the Equality Approach (1980s). Three distinct approaches to women's development have evolved sequentially - Women in Development (WID), Women and Development (WAD), and Gender and Development (GAD) (Momsen, 2004). The WID approach recognized the exclusion of women from the development process and focused on integrating women into it. The WAD perspective emerged in reaction to the limitations of the WID approach and argued that although women were becoming integrated into development processes, this was on unequal terms to men. The GAD approach focuses on empowering women and transforming the unequal relations between women and men which arise from socially defined patriarchal gender norms rather than by biological sex differences. While our purpose here is not to offer a detailed critique of these approaches, they highlight the growing recognition that women's socio-economic participation is integral to sustainable development.

The emergence of the Empowerment Approach in the 1990s (Longwe and Clark, 1994) has acted to analytically amalgamate these strands of debate acknowledging that unequal patriarchal gendered relations are detrimental to the distribution of productive resources. Drawing upon this now somewhat dated, but still influential framework, women's empowerment is defined in terms of five levels of equality. These range from the most basic 
levels of welfare and access, through conscientisation and participation, to the final level of control. Within the global south, strategies aimed at addressing women's empowerment focus on overcoming causes of female disempowerment within the personal, political and economic spheres (Malhotra et al, 2002). Development programmes typically focus on consciousness raising, mobilisation for collective action and grassroots projects developing women's roles in advocacy, democratisation and political action. The use of entrepreneurship as an emancipatory tool for women's empowerment in a context of poverty and patriarchal constraints has attracted increasing attention (Al-Dajani and Marlow, 2013: Hossain, 2012). Within such contexts, the nature and type of entrepreneurial activity women can undertake is determined by family norms, economic constraints and opportunities for social engagement. The production of traditional feminised crafts within the home offers a pragmatic solution to such challenges as it has the potential to generate income, celebrate female skills and enhance individual status whilst not overtly challenging existing family and community relations. Therefore, although this form of home-based self-employment does have some emancipatory potential, this can only be realised by accessing the necessary raw materials and bringing the finished product to market to generate returns.

Consequently, increasing attention has focused upon the role of intermediary organizations as the main mechanisms through which various aspects of micro-enterprise development programming is delivered (Mair et al, 2012; Khavul et al, 2013). Such organizations typically NGOs, social enterprises and various micro-finance initiatives - undertake a vital role in enabling those experiencing poverty and marginalisation to develop the tools and access the resources necessary to address their deprivation with sensitivity to local contexts (Lewis, 2012). NGOs seeking to address poverty alleviation in developing economies, traditionally through micro-enterprise development operate 'with a clear social mission and 
trade (both formal and informal, cash and non-cash transactions) to fulfil that mission' (Luke and Chu, 2012: 772). In addition, other intermediaries include small commercial firms which draw upon local knowledge and networks to engage with home producers providing materials for production and acting as agents to market and sell goods. Collectively, these intermediary organizations offer support, advice and resources that assist local women to develop capabilities to address aspects of their poverty through entrepreneurship.

In reviewing the confluence between the international development and entrepreneurship literatures (Naudé, 2010; 2013), a common theme emerges relating to the opportunity to realise potential to enable greater freedom for functionality and human flourishing. Thus, empowerment at both the individual and community level is central to elicit changes which facilitate development; this argument maps on to Rindova et al's (2009) conceptualisation of emancipatory entrepreneuring. Their thesis suggests that those individuals with very limited resources can effect socio-economic change through entrepreneuring. The core elements of this process evolve from the initial steps of seeking autonomy by 'breaking free from the authority of another' (p.480). This is followed by authorizing him/herself and others in the exchange relationships 'required to pursue change' (p.483) and finally, in making declarations through 'unambiguous discursive and rhetorical acts regarding the actor's intentions to create change - as an important part of the change creation process' (p.485). Quite evidently, however, within the context of desperate poverty in the global south, the emancipatory scope of entrepreneurship requires intermediary intervention which effectively realises the potential of such activity.

\section{Intermediary Organizations, Context and Gender}


Within Jordan, from a total population of 6.4 million, approximately $43 \%$ are of Palestinian origin, with major influxes of Palestinian refugees occurring after the 1948 and 1967 wars (UNRWA, 2010). These Palestinians are formally classified as displaced persons and defined as those 'unable to return to the Palestinian territories occupied by Israel since 1967' (UNHCR, 2009:2). As a displaced population, Palestinians have a precarious legal identity so, for example, have fewer civil rights and limited employment opportunities with associated poverty (Chatty, 2010; Mowafi, 2011). Accordingly, many reside in the most impoverished neighbourhoods, originally refugee camps, in the eastern suburbs of the capital Amman and with an average household income considerably lower than that of the Jordanian population (USAID, 2011).

Given legal restrictions on employment, participation in small-scale enterprise constitutes one of the few available opportunities for income generation (Muzi et al, 2008; Mair and Marti, 2009; Tabbaa, 2010). As women's economic participation is further proscribed by patriarchal cultural norms, the majority of home-based enterprises in the region are women-owned handicraft producers, who share production with other female family members and friends (Al-Dajani, 2007; Chamlou, 2008). In this context, therefore, the home has become a primarily female economic arena enabling craft skills to be passed between generations. Accordingly, NGOs focus upon the home-based handicraft sector for poverty alleviation programmes using micro-enterprise as a development tool entailing subcontracting work to home-based producers, providing materials, specifying designs and paying piece rates for finished items subsequently sold in retail galleries and showrooms in central Amman. In addition to NGO involvement, small independent commercial firms contract home-based producers on a similar basis - providing materials and selling the finished goods. To a greater extent, NGOs frame their intervention as a development programme offering related training 
and support, whereas the commercial contractors focus on the production and marketing function (Al-Dajani, 2007).

While this type of development model has been criticised for sustaining dependency (Fernando, 2003; Meagher, 2010), it does generate pathways for economic participation and social status enhancement for 'hard to reach' groups which remain largely hidden. Indeed, this approach is typical of intermediaries working with disadvantaged communities of women throughout the developing world (Kantor, 2009; Hall et al, 2012). It has also been argued that traditional craft production reproduces gendered labour that limits women's development and empowerment (Vallianatos and Raine, 2007). Such activity however, is often the only link between displaced women and a threatened heritage preserved solely through cultural memories of colours and designs which could otherwise be lost as a consequence of displacement (El Khalidi, 1999). In effect, the celebration and preservation of threatened heritage becomes a political act. This resonates with Parker's (2010: xix) historical analysis of the duality of craft production as both 'a weapon of resistance for women' and a source of constraint; 'it has promoted submission to the norms of feminine obedience and offered both psychological and practical means to independence'. Hence, within a context of constrained socio-economic participation and cultural displacement, craft production can be positioned as enhancing social identity and contributing to a growing sense of empowerment and control over domestic and community resources (Ramussen, 2005: Mair et al, 2012).

Within this particular context, a pertinent feature of the relationship between home-based producers and intermediary organizations is the degree of contractual constraint placed upon the terms and conditions of production. In such instances, individual producers are prohibited from contracting with other intermediary organizations or subcontracting their own work to 
other producers. The underlying reasons for these contractual constraints are complex, and are at least partly rooted in tensions over the ownership of heritage as well as the competition between agencies that has emerged as a consequence of the growing marketization of development aid. The Palestinian heritage handicraft sector in East Amman is highly feminized, intensely competitive and saturated. Traditional embroidery designs are not protected by copyright laws so replication is common. Consequently, there are well-founded concerns that product ideas will be adopted by competitors if production is shared or if a producer contracts with more than one agency. Given their emotional connection with these often historic embroidery designs, it is inevitable that a producer's sense of heritage ownership conflicts with the intermediary's economic ownership of raw materials. However, the use of exclusive contracts is also attributable to a degree of competitive rivalry that exists within the region. NGOs in particular, are reliant upon international aid and charitable funding with predetermined delivery targets encouraging the imposition of exclusive contracting relationships. Failure to meet targets may lead to funding cuts in one agency and greater subsidy of another; hence, there is competition between NGOs whose success is measured in terms of the number of women supported. Individualized production also offers significant managerial advantages to agencies. By denying producers the ability to work together, they are prevented from collective organization and sharing knowledge of better remuneration and benefits offered by alternative agencies such as commercial contractors which compete with NGOs but are able to vary contractual arrangements in response to market shifts.

\section{Analytical Summary}

As Naudé $(2010 ; 2013)$ argues, there is an increasing focus upon the confluence between entrepreneurship and international development with the former being positioned as an 
important element in the solution to poverty and deprivation. Entrepreneurship has the capacity for both social change, by disturbing the status quo, and income generation through the production of marketable goods and services. Hence, it constitutes a pathway to enhance human flourishing through the development of capabilities which inform functioning and choice so enabling individuals to gain greater control and autonomy over their lives (Sen, 1999).

To counter criticisms that entrepreneurship in developing economies, enacted as small scale entrepreneuring and micro-enterprise by the desperately poor, is little more than basic poverty alleviation rather than a source of empowerment (Kuttab; 2010), we note the work of Rindova et al., (2009). Using the construct of emancipation, they argue that entrepreneuring enables the marginalised and disadvantaged to gain degrees of autonomy and effect social change, thus moving beyond mere poverty alleviation. We extend this analysis by contextualising the arguments drawing upon notions of gender and context. Within the fields of both entrepreneurship and international development, the relationship between subordination, gendered ascriptions, women's autonomy and life chances have been recognised. We transpose this analysis into a particular context, focusing upon the displaced Palestinian population in Jordan who, given their marginalised status, experience high rates of poverty. Drawing upon a gendered perspective reveals that for displaced Palestinian women, such disadvantage is compounded by patriarchal cultural norms further entrenching socio-economic subordination. One of the few options available to such women being homebased production of heritage craft goods; in so doing, they protect a threatened culture and elevate their status through the generation of household income. However, to produce and bring the goods to market requires the intervention and support of intermediary organizations as enablers of enterprise. 
Within the international development arena, a diverse range of intermediary organizations operate to support the desperately poor; a critical element of this support being to find local solutions and responses to problems of poverty and deprivation. As such, they act as enabling intermediaries to realise individual and community potential. Of interest and central to this discussion, is the capacity of such intermediaries to facilitate pathways to emancipation for displaced Palestinian women through home-based self-employment. Contracting arrangements, which typically reflect the priorities of the intermediaries, are critical in this process. Thus, we explore how these contractual arrangements shape the emancipatory potential of entrepreneurship to empower those at the base of the pyramid. To empirically illustrate this analysis, we use a micro-enterprise development project in which intermediary organizations contract traditional handicrafts from home-based producers, in order to examine the entrepreneuring of producers and their responses to contractual arrangements. We approach the data using Rindova et al's (2009) theory of emancipatory entrepreneuring in order to consider the actions of some producers resisting contractual constraints, and link this notion to the more established empowerment framework (Longwe and Clarke, 1994), designed to inform development programming.

\section{RESEARCH METHODS}

An interpretivist approach was adopted in this study (Husserl, 1964), reflecting the exploratory nature of the research and desire to give voice to home-based producers and their experiences of entrepreneurship. This was complemented by longitudinal data collection over eight years (1999-2007), which facilitated observation of the lived experiences of participants and development of trust between them and the lead researcher. Framed within this approach, we sought to create a purposeful sample of participants (Patton, 2002) with sufficient 
experience of the phenomena to provide us with rich, fine grained and insightful data. Given the plethora of constraints faced by displaced Palestinian women in East Amman, not least that their entrepreneurial activities were restricted to their homes, we approached eight commissioning organizations (4 NGOs, 4 SMEs). With their assistance, we were able to contact potential participants and create a theoretically relevant sample. We used a number of criteria to create our sample. Participants had to be displaced Palestinian women hence, sharing the same socially and economically marginalized group, and residents of the deprived wards of East Amman which housed the initial refugees in camps in 1967 characterized by overcrowding, dilapidation and poor infrastructure. Sampling criteria also included age, marriage and family situation to ensure that the family-enterprise interface could be explored within the home-based enterprise context. Thus, at the beginning of the study in 1999, participants were aged between 16 and 60 and were, or had been, married with children. Finally, at the start of the study, participants had been supplying one of the eight intermediary organizations for at least two years. By including this criterion, we were able to collect comparative data regarding contractual arrangements, including participant perceptions of intermediary influence upon entrepreneurial activities.

To recruit participants, the Arabic-speaking researcher spent one day at each of the eight intermediary organizations as the home-based producers arrived to deliver their products. The women where approached, informed about the study, invited to contribute and given assurances of anonymity. This sampling approach was effective in securing commitment from 43 home-based producers who were contacted independently of intermediary organizations. Of these, forty were married and three divorced. By the last wave of data collection in 2007, ages ranged between 26-64 years. The majority (28) had completed secondary education, 14 had primary education; one was a university graduate. The average 
number of children was three (minimum one, maximum eight). In 2007, the average length of time participants had supplied their intermediary organization was 15 years. For ethical reasons, in this paper we focus on data drawn from 16 women who described breaching contractual agreements.

\section{Data Collection}

Data were collected using in-depth interviews conducted in Arabic. Over time, as insights emerged and relevant themes surfaced, thematic interview protocols were developed to guide the interviews. These concentrated upon participant experiences of home-based entrepreneurial activities, including perceptions of the contractual obligations with intermediary organizations and their effects and implications. As such, the interviews were framed around 'everyday experiences of entrepreneuring' (Steyaert and Katz, 2004), generating insights into how the women negotiated, interpreted and addressed the realities confronting them on a daily basis in terms of social exclusion, poverty and patriarchal subjugation. All interviews were undertaken by the Arabic-speaking member of the research team, within the homes of participants and lasted between 1.5 and 3 hours. With permission, they were recorded for transcription (in Arabic) with assurances of anonymity and confidentiality; respecting this, pseudonyms are used to protect identities. Evidence was collected in three waves over eight years resulting in 129 transcriptions.

Denzin (1978) describes the collection of data from multiple participants as a form of triangulation; using multiple sources contributes to richer, more complete descriptions of the phenomena under investigation. Combined with the longitudinal nature of our study, the participation of 43 women involved in contractual arrangements with eight intermediaries 
contributed to the collection of robust, reliable data necessary for developing detailed and comprehensive insights into the substantive phenomena (Denzin 1978).

The interpretivist approach combined with depth interviews was appropriate for the exploratory nature of our study. These methodological decisions acknowledge the extent to which Arab culture is both private and oral (Tzanntos and Kaur, 2003; Shalhoub-Kevorkian, 2010), and combined with a longitudinal approach to data collection, facilitated trust-based relationships enabling key themes to emerge and, for participant perceptions of change to be revealed and interpreted. Importantly, our approach enabled the Arabic-speaking member of the research team to engage directly with the participants and so acquire rich accounts of the poorly understood intersection between international development, entrepreneuring and emancipation. Accordingly, participant voices and lived experiences informed and shaped the research process while dialogues remained focused upon the main research topic (Shpungin et al, 2012; Corley and Gioia, 2004).

\section{Data Analysis}

Analysis of the evidence commenced simultaneously with data collection - as is appropriate when research is positioned within an interpretivist approach and depth interviews are employed to explore under-researched phenomena. This provided the opportunity and flexibility to probe potentially interesting issues as they emerged and ensure that, while focused on our substantive research interests, data collection also focused on participant perceptions, experiences and voices. Thus, data collection and analysis were interwoven as interviews commenced (Miles, Huberman and Saladana, 2014) and continued until data became saturated with additional interviews confirming emerging themes, rather than generating new ones (Corley and Gioia, 2004). As such, the approach was iterative involving 
a "recursive process-oriented, analytic procedure" (Locke, 1996: 240). This approach provides "the basis for rigorous collection and analysis of qualitative data and assist [s] in determining the sampling and content foci of later data collection" (Corley and Gioia, 2004: $183)$.

Analysis was guided by the principles of induction (Corbin and Strauss, 2008; Lofland, 1971; Miles and Huberman, 1994). This required scrutinising transcripts, using codes to reduce, order, structure and give meaning to raw data and to identify emerging themes and their related categories. These were compared with the additional data collected and our knowledge of relevant entrepreneurship literature. The Arabic-speaking researcher both collected data and arranged for this to be transcribed (in Arabic). Given the unreliability of qualitative analysis software such as NVivo in right-to-left text (QSR, 2008), coding was undertaken manually; emerging themes and categories within and across interviews were discussed with the research team. This triangulated process of data analysis ensured that emerging themes and related categories were compared both across interviews and with existing theoretical approaches. Critical themes and their related categories were refined, developed, removed and created. As part of the data reduction process, data were organised in tables allowing comparison of emerging themes and categories both across different sources and with existing theories (Miles \& Huberman, 1994).

As all members of the research team share a background in entrepreneurship research and have experience of gender research, entrepreneurial networks and international development, the team was able to draw from a range of theoretical perspectives and entrepreneurship discourses when interpreting and analysing emerging themes. This informed a robust, discussion regarding which themes to pursue collapse or remove from subsequent analyses. 
Importantly, by involving several researchers in these discussions, the team was open to alternative interpretations. This prompted discussion and debate regarding theoretical insights pertaining to women's experiences of home-based entrepreneuring and the effects of varying contractual arrangements with intermediary organizations.

This on-going comparison of themes and categories involved the team in a process similar to constructivist grounded theory (Charmaz, 2006) and served to strengthen the reliability of our analysis. As the research progressed through each of the three phases of data collection, so it became more narrowly focused (Silverman, 2010) on those themes most relevant to understanding the lived experiences of participants and the emancipatory effects of entrepreneurial actions (Rindova et al, 2009). A final important dimension of our analytical process involved sharing and discussing the key findings with research participants. These discussions strengthened the reliability of our findings and helped ensure they were grounded in and gave voice to the experiences of home-based producers. Particular to the findings relating to restrictive contractual arrangements and participant responses to these, we did not share these issues with the intermediary organizations. While this might be conceived as a limitation, we sought to protect the confidentiality promised to all participants.

This cyclical process of coding and comparison (Miles, Huberman and Saldana, 2014), progressing from open or free nodes to identify emerging themes (MacLure, 2013; Strauss and Corbin, 1990) through to axial codes identifying relationships between categories and ultimately higher-order codes (Strauss and Corbin, 1990; Marlow and McAdam, 2012), has been utilised in numerous qualitative studies (see: Corley and Gioia (2004) and Marlow and MacAdam (2012)). Echoing this work, the process of inductive, triangulated analysis identified a number of higher-order themes emerging from the lived experiences of these 
desperately poor women engaging in entrepreneuring to improve their economic and social situation. Drawing from these themes, the findings focus upon the diverse contractual arrangements - how the women related to them and their reasons for such behaviours. These analytical themes, their respective categories and examples of the raw data from which they emerged are presented in Table 1.

Inevitably, the study presented a number of ethical considerations that were, to some extent, resolved by the use of a longitudinal approach to data collection and publication. We were privileged to share in the confidences of participants, a situation enabled by developing trust over several years of data collection. During this time, we deliberately kept a low profile within the locality, ensuring anonymity and confidentiality among participant families, business associates and market intermediaries, as well as within any publications. Hence, any identifying characteristics of the participants and neighbourhoods have been removed from this paper, and pseudonyms are used to protect identities. To ensure accurate translation of the quotes presented in this paper, translation from Arabic to English and back to Arabic was implemented by the Arabic-speaking researcher (native Arabic, fluent English), and another bi-lingual professional researcher.

\section{INSERT TABLE 1 ABOUT HERE}

\section{FINDINGS}

Variations in contracting arrangements were initially found during the first phase of data collection. Comparisons across the 22 women supplying NGOs, and the 21 women supplying SMEs, revealed that five intermediary organizations (4 NGOs, 1 SME) imposed exclusive contracts with producers, prohibiting their engagement with other intermediaries and 
producers. The responses to and implications of these conditions were explored in the subsequent phases of data collection. In the second phase, ten women (nine contracted to NGOs, one contracted to SME1) described breaching exclusive restrictions by covertly contracting with additional intermediary organizations. In the final phase, sixteen women (15 contracted to NGOs, one contracted to SME1) described breaching restrictions on producer association by participating in collaborative production networks. These women named further eight participants who also participated in these proscribed production networks; however, for ethical reasons, data discussed in this paper are drawn only from the sixteen women who voluntarily described activities that contravened contracts.

Table 2 provides details of the sample of participants and intermediary organizations. As this illustrates, all four NGOs and one commercial firm (SME1) used restrictive contracts forbidding producers from engaging with alternate intermediary organizations or sharing production. Unlike the five restrictive intermediaries, three commercial firms (SME2, SME3, SME4) imposed no restrictions on producers either in their engagement with additional intermediaries or in collaborative production. Table 2 provides details of participant age, education level, length of time supplying the intermediary organization and, for participants supplying restrictive intermediaries, whether they breached the terms of their contracts by contracting with multiple intermediaries or by participating in collaborative production. It is notable that producers supplying SME1 (a restrictive organization) received the highest returns, being paid hourly rather than piece rates, substantially increasing average earnings; notably however, this still fell below the Jordanian poverty line. None of the producers contracted to SME1 discussed their participation in collaborative production networks, though Muna implicated three other women, explaining that, "They are too afraid that the owner will find out - she is ruthless". Women supplying restrictive organizations were 
slightly younger and earned slightly more than those supplying non-restrictive organizations. The data presented in this paper are drawn from the third wave of data collection which focused on responses to contracting conditions. The sixteen women who described their role within a proscribed collaborative production network are identified in the final column of Table 2.

INSERT TABLE 2 ABOUT HERE

The use of collaborative production networks, prohibited by some intermediaries but necessary for efficient production, first emerged during the second-wave of data collection, during interviews with Jalila, Lubna, Muna, Ghalia and Sundos, the founders and leaders of three production networks. In the third wave of data collection, a further eleven participants also described breaching contractual terms by engaging in collaborative production. Collectively, these sixteen women implicated a further eight study participants who breached the terms of their contracts, engaging with multiple intermediaries and being active members of collaborative production networks, though they chose not to disclose this (Maysa, Riham, Nur, Hidaya, Manal, Rana, Lamis and Sara, identified* in Table 2).

Protecting the identities of participants who breached contractual terms to ensure that safety, security, livelihoods and networks were not jeopardised by this research was an important priority. Laila explained the consequences of breaching their contracts and participating in a collaborative production network: "If the organization finds out, not only will they never give me work again, but no other organization will ever give me work ... it is very serious". Collaborative production networks were formed by women living within close proximity and sharing established social relationships. Within these networks, women subcontracted work 
to each other, pooled labour and work resources, shared childcare and domestic work. Such activities were deliberately hidden from contracting organizations, competing producers, some family members (including husbands) and members of the wider community. Participant motivations for collaborative production encompassed social and economic factors. These included overcoming the isolation of home-based work, sharing childcare and enhanced earnings plus, a degree of satisfaction from controlling production leading to greater efficiencies and higher quality outputs (Table 1). Although one of the benefits of these hidden networks was the ability to share domestic work, this also helped camouflage collective economic activities. As Juhaina explained, "Sharing childcare, cooking, cleaning and making or mending clothes and so on is a perfect cover for our real work in the group. No one doubts what we are getting up to so no-one asks either ... As long as we are in the community and not spending what others think we don't have, no-one bothers us". Fatima described how the networks operated in practice: "We don't have any childcare facilities here so we have to rely on each other. We take it in turn to look after each other's children and sometimes I might look after six or eight children while their mothers get on with the work."

A web of affinal and kinship relationships linked the three networks, labelled the Beit Dajan, Bethlehem and Ramallah networks, in reference to traditional Palestinian embroidery styles and techniques (Figure 1). Members of the Beit Dajan network, led by Sundos, were all subcontracted by NGO4, lived within walking distance of each other and shared family ties. The Bethlehem network was led by Lubna, and the trio here were all subcontracted by NGO2 and had ties to other home-based women producers not included in this study. In both the Beit Dajan and Bethlehem networks, the members initially collaborated on contracts from their respective NGOs, but this collaboration grew to encompass contracts and clients from 
further afield. The Ramallah network was predominantly facilitated by the Beit Dajan group, whereby work was commissioned and subcontracted to other home-based producers not included in this study.

While these three networks sometimes operated independently, they were also integrated into a single over-arching network comprising the five network founders (Jalila, Lubna, Muna, Ghalia and Sundos). Figure 1 maps the network links, where the dotted boundary lines around the Beit Dajan and Bethlehem sub-networks represent their independence as well as interconnectedness with each other and with the Ramallah sub-network. The relationships, highlighted in Figure 1, are based on data obtained from sixteen women who described their engagement in collaborative production networks. The five network founders (Jalila, Lubna, Sundos, Muna and Ghalia) undertook a key role in bridging the three sub-networks, with Muna being particularly instrumental in facilitating contracts. Overall, the findings revealed three overlapping sub-networks clustered around the five leaders (network brokers) who took a leading role in organizing contracts and labour, uniting the sub-networks and creating a single overarching network.

\section{INSERT FIGURE 1 ABOUT HERE}

\section{DISCUSSION}

These findings highlight the importance of context in entrepreneurial actions, demonstrating the necessity for the network and member actions to remain hidden. Such concealment has hitherto restricted external observation and recognition by the research community (Rowbotham and Mitter, 1994; Kabeer, 2004; Williams and Round, 2007). The accidental discovery of such networks arose from high levels of trust developed over several years of 
research inquiry. Within this section, we discuss these findings against the theoretical framework of emancipatory entrepreneuring (Rindova et al, 2009) to explore the extent to which these actions contributed to empowerment and emancipation opportunities.

The core elements of emancipatory entrepreneuring (seeking autonomy, authoring exchange relationships, making declarations) were originally illustrated using Google's founders to retrospectively identify separate and distinctive emancipatory actions (Rindova et al, 2009). However, within this sample of displaced women at the 'base of the pyramid', actions relating to their search for autonomy and authoring exchange relationships overlapped in practice and were analytically indivisible. We argue that the first stage of emancipatory entrepreneuring, seeking autonomy, is evident in the decision by some participants to breach the terms of their contracts by engaging with multiple intermediaries. The second stage, authoring exchange relationships, is evident in the creation of networks of collaborative production, prohibited by some intermediaries but vital to enhanced productivity. Although some may view the deliberate breach of contracts as unethical, it should be noted that three of the intermediary organizations (all SMEs) did not impose prohibitions on association or collaborative production - a fact widely known to study participants. In this light, the decision by some intermediaries to impose contractual prohibitions appears anomalous and driven by managerial convenience rather than market necessity. Among NGOs, this practice runs counter to their intended mission to facilitate women's empowerment. Given the social and geographical restrictions imposed upon home-based producers, few could exercise the choice to contract with alternate intermediaries. Hence, the decision by some producers to seek multiple contracts and collectively organise production might be interpreted as a rational response to their predicament. Such a response ensures the potential to increase individual 
income, enhance the social enjoyment of labour, and quietly subvert an imposed social order that casts these women as docile beneficiaries, rather than authors of their own future.

It is pertinent that three of the five founders (Jalila, Lubna and Muna) were divorced and, in a society where divorce is both rare and prompts disapproval (UNIFEM, 2004), these women were largely ostracized within their own communities. As Lubna explained, "My participation in this circle is not a choice, I have to... As a divorcee where else can I get support from? How will I feed my children if I don't embroider?" Although the initial aim of the network was to create economic advantage, working together helped the women to build a sense of collective solidarity, a haven against community patriarchy as well as restrictive market intermediaries. Networks offered social and economic support, providing unavailable services such as childcare, and the opportunity to take on additional clients - this was both easier and safer within a group than as an individual. Rivals and competitors comprised other home-based producers outside their own network, usually beyond the immediate vicinity, whilst mobility was restricted by poor public transport and cultural norms hindering independent travel by women. These conditions contributed to the creation of a collective identity within each network (Portes and Haller, 2005); their bonds and sense of community developed as they worked together, in turn helping to retain secrecy and exclusivity among network members.

Although Rindova et al (2009) identified the act of making declarations as integral to emancipatory entrepreneuring, our study demonstrates how difficult this can be for displaced, bottom of the pyramid communities. We interpret the final stage of emancipatory entrepreneuring, declarative statements of intent to change, as analogous to revealing participation in collaborative production networks. Within our study, keeping production 
networks hidden was necessary to their continued existence. Evidently, intermediary organization were either unaware or chose to ignore production networks, and given the sensitivities surrounding their existence, ethical considerations prevented discussion with intermediaries. Similarly, earnings from collaborative production were often concealed both from tax authorities, enabling them to continue receiving UNRWA financed social transfers, and from husbands, who could neither claim nor control this income. By deliberately excluding men and other community members, these women have created among themselves a legitimating exclusivity and a private space for their collective identity. However, as they cower from publicly 'making declarations' and maintain the hidden nature of their network, it is necessary to consider the extent to which their activities may be considered emancipatory.

At the individual level, their resistance to authority and regulation appears to fulfil a sense of achievement and personal satisfaction, a positive social identity, and financial contributions to their families which often exceed those provided by their husbands. Arguably, this may be interpreted as empowering rather than emancipatory, as no significant change to their sociopolitical positioning, citizenship status or gender roles has been achieved.

\section{CONCLUSIONS}

Within this paper, our critical research objective focused upon an empirically informed exploration of the role of intermediary organizations in enhancing the emancipatory prospects of desperately poor women through micro-entrepreneuring activities. Drawing upon arguments by Sen (1999), Bruton et al., (2009) and Rindova et al, (2009), we acknowledge that to advance understanding, issues of context, gender and human development should be analytically amalgamated. Hence, our study was informed by relevant literatures that 
underpin themes relating to gender and development, emancipatory entrepreneuring, and the efficacy of intermediary organizations. These act as a platform to reveal and explore the potential of entrepreneuring as an emancipatory activity for displaced women in a developing economy context. In so doing, we extend contemporary debate in demonstrating the need for a more nuanced, encompassing approach to effectively evaluate the potential of entrepreneurship as a source of emancipation for the desperately poor. Accordingly, within this paper we respond to claims of the parochial nature of entrepreneurship theorising by extending this analysis to those experiencing poverty and displacement in the global south.

Our analysis presents empirical evidence exploring the experience of displaced Palestinian women in Jordan operating as home-based producers, observing and analysing their relationships with intermediary organizations. The research site offers an important empirical contribution offering voice and visibility to a 'hard to reach' group of women while responding to calls for more longitudinal, multi-disciplinary research which involves local researchers and activists (Bruton et al., 2009). In this particular context, the evidence reveals how the blurring of altruistic and market relations add layers of complexity to interactions with intermediary organizations. These relationships are imbued with tensions over the ownership and commodification of heritage, constraints in producer ability to contract with more competitive organizations, and the conflicting roles of such organizations who simultaneously act as patron-donors and client-contractors. The introduction of local rules preventing women from undertaking shared production or establishing client-based relations with alternative agencies - mechanisms that are clearly designed to influence market relations - inevitably spill-over to affect and distort altruistic relations. Displaced women are cast as beneficiaries requiring protection, but also as low cost producers whose efficiency is contingent upon managerial intervention in the shape of contractual constraints. Such 
constraints however, are not uniformly applied with many commercial intermediaries tolerating collaboration and multiple contracting. Thus, there is a diverse managerial model which reflects both market competition and also the priorities of NGOs to maintain their funding. These may not necessarily accord with the ambition of realising the entrepreneurial emancipation and enhancing returns to the producers.

The contracting restrictions imposed by some intermediary organizations clearly contributed to the continued impoverishment of many producers. A longitudinal data collection approach illustrated that home-based producers were able to generate a degree of economic sustenance through their craft production over many years, but that restrictive practices prevented them from ever being able to effectively break through the poverty line. It is important to stress that although contracting restrictions are a common practice they are not universally adopted. Women contracted by three of the eight intermediary organizations in this study were free to associate with other producers and share collaborative production, and so achieved greater efficiencies and higher incomes. This suggests that restrictive contracting is an unnecessary imposition that, while managerially convenient for intermediary organizations, places an additional constraint on already overburdened and impoverished producers.

The mixed and somewhat instrumental approach to contracting by intermediary organizations undermines the ethos of the Rindova et al's (2009) thesis in terms of its critical themes of autonomy, authoring and making declarations. Indeed, analysing the experiences of those who contributed to this study suggests that entrepreneuring was pursued as one of the few means available to 'get by' rather than 'break free'. Paradoxically however, the prohibitive conditions arising from restrictive contracts, tight markets and contractor prerogative elicited entrepreneurial solutions from the study participants. These women responded to such 
constraints by navigating and negotiating pathways to challenge and dispute the confines of contractual relationships.

As with any study, we recognise limitations but suggest these offer scope for future research. For reasons of confidentiality we were not able to discuss our findings with the intermediary organizations involved, thus future work needs to return to these organizations to explore their managerial rationale. As a qualitative study, we can only generalise to theory but would argue that large scale surveys are not practical for such hard to reach groups; however, further longitudinal studies of those at the bottom of the pyramid in other locations are essential to build upon this work. Finally, given the continued volatility within the region, changes in the nature and origin of displaced people and effects upon local markets for craft goods requires further evaluation. Accordingly, it is necessary to expand the analysis of international development, entrepreneurship and emancipation to look beyond the assumption of a simple relationship between these constructs. Taking account of how emancipatory potential is mediated by other influences, such as intermediary organizations, whose mission to assist the desperately poor is tailored to their own organizational objectives and priorities, is now essential in order to advance this debate. 


\section{REFERENCES}

Al-Dajani, H. (2007), 'Women's Empowerment: A Comparison Between Non-Profit and For-Profit Approaches in Empowering Home-based Women Producers', Unpublished PhD Thesis, University of Strathclyde.

Al-Dajani, H., \& Marlow, S. (2013). 'Empowerment and entrepreneurship: a theoretical framework'. International Journal of Entrepreneurial Behaviour \& Research, 19(5), 4-4.

Ahl, H. (2006), Why Research on Women Entrepreneurs Needs New Directions. Entrepreneurship Theory and Practice, 30: 595-621.

Ansari, S. Munir, K. and Gregg, T. (2012), 'Impact at the 'Bottom of the Pyramid': The Role of Social Capital in Capability Development and Community Empowerment'. Journal of Management Studies, 49, 813-842.

Bruni, A. Gherardi, S. and Poggio, B. (2004), Doing gender, doing entrepreneurship: an ethnographic account of intertwined practices. Gender, Work and Organization 11(4): 406-429.

Bruni A Gherard S and Poggio B (2005) Gender and entrepreneurship: an ethnographical approach. Abingdon, Oxon: Routledge.

Bruton, G. D., Ahlstrom, D., \& Obloj, K. (2008). Entrepreneurship in emerging economies: Where are we today and where should the research go in the future. Entrepreneurship theory and practice, 32(1), 1-14.

Calás, M.B. Smircich, L. and Bourne, K.A. (2009). 'Extending the Boundaries: Reframing "Entrepreneurship as Social Change" Through Feminist Perspectives'. Academy of Management Review, 34, 552-569.

Carter, S. and Shaw, E. (2006). Women's Business Ownership: Recent Research and Policy Developments. London: DTI Small Business Service Research Report, November 2006, 96pp.

Chamlou, N. (2008). The Environment for Women's Entrepreneurship in the Middle East and North Africa Region. The World Bank, Washington DC.

Charmaz, K. (2006). The power of names. Journal of Contemporary Ethnography, 35(4), 396-399.

Chatty, D. (2010). Displacement and Dispossession in the Modern Middle East, Cambridge: Cambridge University Press.

Corbin, J., Strauss, A., 2008. Basics of Qualitative Research: Techniques and Procedures for or Developing Grounded Theory, Sage, London, 3rd Edition.

Corley, K. G., \& Gioia, D. A. (2004). Identity ambiguity and change in the wake of a corporate spin-off. Administrative Science Quarterly, 49(2), 173-208. 
Denzin, N.K., 1978. Sociological Methods: A Source of Book. McGraw Hill, New York.

Dreze, J. and Sen, A. (1989), Hunger and Public Action. Oxford: Oxford University Press.

El-Khalidi, L. (1999). The Art of Palestinian Embroidery. Saqi Books, London.

Fernando, J.L. (2003). 'The Power of Unsustainable Development: What is to be Done?' Annals of the American Academy of Political and Social Science, 59, 6-34.

Hall, J. Matos, S. Sheehan, L. and Silvestre, B. (2012). 'Entrepreneurship and Innovation at the Base of the Pyramid: A Recipe for Inclusive Growth or Social Exclusion?' Journal of Management Studies, 49, 785-812.

Hossain, N. (2012). Security and the Pathways of Women's Empowerment: Findings from a Thematic Synthesis of the Pathways of Women's Empowerment Research. IDS Working Papers, 2012(406), 1-48.

Hughes, K.D., Jennings, J.E., Brush, C., Carter, S., and Welter, F. (2012) 'Extending Women's Entrepreneurship Research In New Directions' Entrepreneurship Theory \& Practice Vol. 36, No. 3, pp. 429-442.

Husserl, E., 1964. Idea of Phenomenology. Kluwer Academic Publishers.

Kabeer, N. (2004), 'Globalization, Labor Standards, and Women's Rights: Dilemmas of Collective (In)Action in an Interdependent World'. Feminist Economics, 10, 3-35.

Kantor, P. (2009). 'Women's Exclusion and Unfavorable Inclusion in Informal Employment in Lucknow, India: Barriers to Voice and Livelihood Security'. World Development, 37, 194-207.

Khavul, S. Chavez, H. and Bruton, G. (2013). When Institutional Change Outruns the Change Agent: The Contested Terrain of Entrepreneurial Microfinance for those in Poverty. Journal of Business Venturing, 28, 30-50.

Kuttab, E. (2010). Empowerment as Resistance: Conceptualizing Palestinian women's empowerment. Development, 53(2), 247-253.

Lewis, K. (2012). The power of interaction rituals: The Student Volunteer Army and the Christchurch earthquakes, International Small Business Journal, 31: 811-831.

Locke, K. (1996). Rewriting the discovery of grounded theory after 25 years? . Journal of Management Inquiry, 5, 239-245.

Lofland, J., 1971. Analysing Social Settings: A Guide to Qualitative Observation and

Longwe, S., and Clarke, R. (1994), 'Women in Development, Culture and Youth', in Workshop Preparatory Readings, 1-3, April - December 1994, Lusaka: Longwe Clarke Associates. 
Luke, B. and Chu, V. (2012), Social Enterprise versus Social Entrepreneurship: An Examination of the 'Why' and 'How' in Pursuing Change. International Small Business Journal, 31: 764-784.

MacLure, M. (2013). Researching without representation? Language and materiality in postqualitative methodology. International journal of qualitative studies in education, 26(6), 658-667.

Mair, J. and Marti, I. (2009). Entrepreneurship In and Around Institutional Voids: A Case Study from Bangladesh. Journal of Business Venturing, 24, 419-435.

Mair, J., Marti, I. and Ventresca, M. (2012) Building Inclusive Markets in Rural Bangladesh: How Intermediaries Work Institutional Voids. Academy of Management Journal, 55 (4), 819-850.

Malhotra, A, Schuler, S. and Boender, C. (2002), Measuring Women's Empowerment as a Variable in International Development. Washington DC.: International Center for Research on Women and the Gender and Development Group of the World Bank.

Marlow, S. (2014), Exploring future research agendas in the field of gender and entrepreneurship, International Journal of Gender and Entrepreneurship. 6: 2.102 120

Marlow, S. and Ahl, H. (2012), "Exploring the dynamics of gender, feminism and entrepreneurship: advancing debate to escape a dead end", Organization, Vol.19 (5), pp. 543-562.

Marlow, S., \& McAdam, M. (2012). Analyzing the influence of gender upon hightechnology venturing within the context of business incubation. Entrepreneurship Theory and Practice, 36(4), 655-676.

Meagher, K. (2010). 'The Empowerment Trap: Gender, Poverty and the Informal Economy in sub-Saharan Africa', in Chant, S. (Ed) The International Handbook of Gender and Poverty: Concepts, Research, Policy. Cheltenham: Edward Elgar.

Miles, M.B., and Huberman, A.M., 1994. An Expanded Sourcebook : Qualitative Data Analysis. London: Sage.

Miles, M, Huberman, A. M., \& Saldaña, J. (2014). Qualitative Data Analysis: A Methods Sourcebook. Sage.

Mole, K. and Ram, M. (2012) Perspectives in Entrepreneurship, London, Palgrave.

Momsen, J. (2004) Gender and Development, London, Routledge.

Mowafi, H. (2011). 'Conflict, Displacement and Health in the Middle East'. Global Public Health, 6, 472-487. 
Muzi, S. Ahmed, H. and Chamlou, N. (2008). Women Labour Force Participation, Education and Non-Economic Factors: The Case of Middle East and North Africa Countries, Washington DC: World Bank MENA Region Chief Economist Office.

Naudé, W. A. (2010), Entrepreneurship is not a binding constraint on growth and development in the poorest countries, World Development, 39 (1) $33-44$.

Naudé, W. A. (2013). Entrepreneurship and economic development: Theory, evidence and policy (No. 7507). IZA Discussion Paper.

Oxaal, Z. and Baden, S. (1997). Gender and Empowerment: Definitions, Approaches and Implications for Policy. Brighton: Institute of Development Studies, University of Sussex.

Parker, R. (2010) The Subversive Stitch: Embroidery and the Making of the Feminine. London: Tauris

Patton, M. Q., 2002. Qualitative Research \& Evaluation Methods. Sage Publications,

Portes, A. and Haller, W. (2005). 'The Informal Economy', in Smelser, N.J. and Swedberg, R. (Eds) The Handbook of Economic Sociology Princeton NJ: Princeton.

QSR, (2008). http://www.qsrinternational.com/support_faqs_detail.aspx?view=358. (accessed February 2009).

Ramussen, S. (2005). 'Tuareg Diaspora', in Ember, M. Ember, C. and Skoggard, I. (Eds) Encyclopaedia of Diasporas, Los Angeles: Springer.

Rindova, V. Barry, D. and Ketchen, D Jr. (2009). 'Introduction to Special Topic Forum: Entrepreneuring as Emancipation'. Academy of Management Review, 34, 477-491.

Rowbotham, S. and Mitter, S. (1994), Dignity and Daily Bread: New Forms of Economic Organising Among Poor Women in the Third World and the First, London: Routledge

Sen, A. (1985), Wellbeing, Agency and Freedom: The Dewey Lectures 1984. Journal of Philosophy, 82: 169-221.

Sen, A. (1999) Development as Freedom. Oxford: Oxford University Press.

Shalhoub-Kevorkian, N. (2010), 'Palestinian Women and the Politics of Invisibility: Towards a Feminist Methodology'. South Asian Journal of Peacebuilding, 3, 1-21.

Shpungin, E. Allen, N. Loomis, C. and DelloStritto, M. E. (2012), 'Keeping the Spirit Alive: Using Feminist Methodology to Address Silencing', Journal of Community Psychology, 40, 44-61.

Silverman, D. (Ed.). (2010). Qualitative research. Sage. 
Steyaert, C. and Katz, J. (2004). 'Reclaiming the Space of Entrepreneurship in Society: Geographical, Discursive and Social Dimensions'. Entrepreneurship \& Regional Development, 16, 179-196

Strauss, A., \& Corbin, J. M. (1990). Basics of qualitative research: Grounded theory procedures and techniques. Sage Publications, Inc.

Tabbaa, Y. (2010). Female Labour Force Participation in Jordan, Economic and Social Council Policy Papers, Amman - Jordan. http://esc.jo/en/female-labour-forceparticipation-jordan (accessed December 2010).

Tzanntos, Z. and Kaur, I. (2003). 'Women in the MENA Labour Market', in Doumato, E.A. Posusney, M.P. (Eds) Women and Globalization in the Arab Middle East, Colorado: Lynne Reiner Publishers.

UNHCR, (2009). UNHCR Revised Note on Article 1D of the 1951 Convention. UNHCR: New York.

UNIFEM, (2004). Progress of Arab Women. UNIFEM: Amman.

UNRWA, (2010). Jordan Facts, http://www.unrwa.org/etemplate.php?id=66. United Nations Relief and Works Agency (accessed October 2011).

USAID, (2011). Strategic Statement Jordan 2007 - 2011, United States Agency for International Aid http://pdf.usaid.gov/pdf docs/PDACN487.pdf (accessed October 2011).

Vallianatos, H. and Raine, K. (2007). 'Reproducing Home: Arab Women's Experiences of Canada'. Al-Raida, 24, 35-51.

Williams, C. C., \& Round, J. (2007). Entrepreneurship and the informal economy: a study of Ukraine's hidden enterprise culture. Journal of developmental entrepreneurship, 12(01), 119-136.

Zahra, S., Wright, M. and Abdelgawad, S. (2014) Contextualization and the advancement of entrepreneurship research, International Small Business Journal, 32 (5) 479-501. 
Table 1: Varying Contractual Arrangements: Analytical Themes, Categories and Examples of Raw Data

\begin{tabular}{|c|c|c|}
\hline Analytical themes & Categories & Examples of raw data \\
\hline A.T. 1 & CAT. 1 & $\begin{array}{l}\text { "If the organization finds out, not only will they never give me work again, but no other organization } \\
\text { will ever give me work ... it is very serious."(Laila) }\end{array}$ \\
\hline \multirow[t]{2}{*}{$\begin{array}{l}\text { Varying } \\
\text { contractual } \\
\text { arrangements }\end{array}$} & Restrictive & $\begin{array}{l}\text { "It takes tremendous energy, time and commitment to create the circle that we have and the trust that } \\
\text { we share. Everyone in our circle has lived the benefits of sharing the work and the clients, so why } \\
\text { would they stop now?" (Lubna) } \\
\text { "Everyone does it. It is not like we are breaking the law." (Alia) }\end{array}$ \\
\hline & $\begin{array}{l}\text { CAT. } 2 \\
\text { Not } \\
\text { restrictive }\end{array}$ & $\begin{array}{l}\text { "I have many clients, and in fact they introduce me to their friends and recommend me to other } \\
\text { organizations because they like my work." (Samira) } \\
\text { "Since my boss moved to Canada, I have many new customers coming from there in the summer, and } \\
\text { they all say that she told them about me." (Nihaya) }\end{array}$ \\
\hline \multirow[t]{2}{*}{$\begin{array}{l}\text { A.T. } 2 \\
\text { Responses to } \\
\text { contractual } \\
\text { arrangements }\end{array}$} & $\begin{array}{l}\text { CAT. } 1 \\
\text { Secret } \\
\text { collaboration }\end{array}$ & $\begin{array}{l}\text { "The client must only see the woman she commissioned, not the whole army of us behind her and the } \\
\text { same is true for the contractors' representatives. They will kill us otherwise." (Alia) } \\
\text { "No-one can understand how separate we are from the rest of the world unless they are part of our } \\
\text { community. There are so many barriers that determine what we can and can't do, where we can and } \\
\text { can't go, what we can and can't say. No one will change that for us, we have to change it for ourselves, } \\
\text { us women I mean. That's what this circle does - it removes the barriers, but if others outside the circle } \\
\text { find out about it, they will destroy everything we have built."(Sundos) } \\
\text { "We don't need any man in our circle, they don't understand about our work, or the way we do things. } \\
\text { If my husband knew about me participating in this circle, he would stop me because he thinks other } \\
\text { women will be a bad influence on me, of course unless it is his mother or his sisters."(Maha) }\end{array}$ \\
\hline & $\begin{array}{l}\text { CAT. } 2 \\
\text { Work with } \\
\text { multiple } \\
\text { clients }\end{array}$ & $\begin{array}{l}\text { "Life would be so much easier if I didn't have to find so many different contracts all the time ... If I } \\
\text { could find one big and regular contract it would be great." (Jiman) } \\
\text { "Being able to decide which clients to take on and which ones not to is excellent. I should not turn } \\
\text { away work but, for me, I have to like the client too." (Malak) } \\
\text { "This business is very competitive and it is tough to secure many contracts when you are not famous } \\
\text { like some of the other embroiderers in my neighbourhood." (Dara) }\end{array}$ \\
\hline $\begin{array}{l}\text { Motivations for } \\
\text { breaching contracts }\end{array}$ & Economic & $\begin{array}{l}\text { "Do you know anyone who can live on 60, 70, 80, } 90 \text { even } 100 \text { dinars a month, let alone support a } \\
\text { family with that? I'm sure you see then that we have to supplement this income even if the } \\
\text { organizations don't allow it." (Khadija) } \\
\text { "When you have no choices available to you to improve your life and your children's lives, you have to }\end{array}$ \\
\hline
\end{tabular}




\begin{tabular}{|c|c|c|}
\hline & & $\begin{array}{l}\text { take action and be resilient to the obstacles. That resilience makes you creative, so we identified where } \\
\text { our lives needed to be improved and designed ways in which we could achieve that [improvement] ... } \\
\text { For example, we didn't want to remain poor and we didn't want to see our children grow up poor ... } \\
\text { The only way forward was through our embroidery, but working on your own you only have two hands } \\
\text { and } 24 \text { hours in a day. We had to work together, even if our organizations wouldn't allow it" (Ghalia). }\end{array}$ \\
\hline & $\begin{array}{l}\text { CAT. } 2 \\
\text { Social } \\
\text { support }\end{array}$ & $\begin{array}{l}\text { "We are very protective of our circle and each other. We share everything between us. It is great." } \\
\text { (Maryam) } \\
\text { "He [husband] works away from home but his mother lives nearby and keeps an eye on me and the } \\
\text { children. If she found out that I'm working like this, it will probably be the end of my marriage." } \\
\text { (Nafisa) } \\
\text { "Sharing childcare, cooking, cleaning and making or mending clothes and so on is a perfect cover for } \\
\text { our real work in the group. No one doubts what we are getting up to so no-one asks either... As long as } \\
\text { we are in the community and not spending what others think we don't have, no-one bothers us." } \\
\text { (Juhaina) } \\
\text { "Sharing the work makes it more fun and a great excuse to get out of the house to visit the others" } \\
\text { (Jalila). } \\
\text { "At the end of the day, all the organization cares about is the product I make and give them, not about } \\
\text { me. Even after all these years of giving them my best work, they still threaten that I can be replaced } \\
\text { tomorrow - just like that. So I have developed a very thick skin now and I really don't care if they } \\
\text { replace me tomorrow, now I know they need me more than I need them. ... But the other embroiderers } \\
\text { and I, we do care about each other. We live in the same neighbourhood, our children go to school } \\
\text { together. We are one community, our lives affect each other every day. If something happened to any of } \\
\text { us, we all help each other... we only have each other" (Fatima). }\end{array}$ \\
\hline & $\begin{array}{l}\text { CAT. } 3 \\
\text { Embroidery } \\
\text { production } \\
\text { control }\end{array}$ & $\begin{array}{l}\text { We have a strong circle [of embroiderers] here and we produce the best embroidery in the country. We } \\
\text { also don't want any embroiderers from anywhere joining our circle. It doesn't work like that."(Nafisa) } \\
\text { "We don't distinguish between clients. Wherever the work is coming from, we share it between us } \\
\text { depending on what is required and who are the most suitable for doing it." (Majida) } \\
\text { "If we did not work collectively on our contracts, firstly we would never get the work finished on time } \\
\text { as we are given very unrealistic deadlines and secondly, we would get very lonely" (Sundos) } \\
\text { "To avoid the agency giving our work to others, we share our work with embroiderers we trust, and } \\
\text { whose quality is excellent. We also help them with their contracts too. During these times there is such } \\
\text { a buzz, it is like preparing for your daughter's wedding, stressful but exciting too." (Jalila) }\end{array}$ \\
\hline
\end{tabular}


Table 2: Summary of Participant Producers

\begin{tabular}{|c|c|c|c|c|c|c|c|c|}
\hline $\begin{array}{l}\text { Inter- } \\
\text { mediary }\end{array}$ & $\begin{array}{l}\text { Pseudo- } \\
\text { nym }\end{array}$ & Age & $\begin{array}{l}\text { Education } \\
\text { Level }\end{array}$ & $\begin{array}{l}\text { No. of } \\
\text { Children }\end{array}$ & $\begin{array}{l}\text { Years } \\
\text { with inter- } \\
\text { mediary }\end{array}$ & $\begin{array}{l}\text { Monthly } \\
\text { earnings } \\
\text { (£) }\end{array}$ & $\begin{array}{l}\text { Multiple } \\
\text { contract }\end{array}$ & $\begin{array}{l}\text { Producer } \\
\text { network }\end{array}$ \\
\hline \multirow{5}{*}{$\begin{array}{l}\text { NGO1 } \\
\text { Restrictive }\end{array}$} & Jalila + & 44 & Secondary & 1 & 17 & 68 & No & Yes \\
\hline & Manal* & 47 & Secondary & 5 & 17 & 69 & No & No \\
\hline & Rana* & 42 & Secondary & 1 & 14 & 65 & No & No \\
\hline & Noura & 34 & Secondary & 1 & 10 & 60 & Yes & Yes \\
\hline & Madiha & 36 & Secondary & 3 & 12 & 57 & No & No \\
\hline \multirow{6}{*}{$\begin{array}{l}\text { NGO2 } \\
\text { Restrictive }\end{array}$} & Laila & 61 & Primary & 5 & 16 & 75 & Yes & Yes \\
\hline & Hana & 38 & Secondary & 1 & 13 & 40 & No & No \\
\hline & Lubna + & 31 & Primary & 2 & 13 & 68 & Yes & Yes \\
\hline & Alia & 29 & Secondary & 1 & 11 & 50 & Yes & Yes \\
\hline & Nafisa & 34 & Secondary & 2 & 16 & 70 & Yes & Yes \\
\hline & Marwa & 37 & Secondary & 3 & 15 & 73 & No & No \\
\hline \multirow{5}{*}{$\begin{array}{l}\text { NGO3 } \\
\text { Restrictive }\end{array}$} & Muna + & 42 & Secondary & 3 & 18 & 60 & Yes & Yes \\
\hline & Khadija & 64 & Primary & 8 & 19 & 90 & Yes & Yes \\
\hline & Maha & 62 & Primary & 7 & 27 & 85 & Yes & Yes \\
\hline & Lamis* & 36 & Secondary & 3 & 17 & 68 & No & No \\
\hline & Sara* & 40 & Secondary & 3 & 21 & 70 & No & No \\
\hline \multirow{6}{*}{$\begin{array}{l}\text { NGO4 } \\
\text { Restrictive }\end{array}$} & Maryam & 26 & Secondary & 1 & 10 & 40 & No & Yes \\
\hline & Fatima & 48 & Secondary & 3 & 12 & 55 & No & Yes \\
\hline & Adila & 29 & Secondary & 1 & 12 & 52 & No & Yes \\
\hline & Majida & 30 & Secondary & 1 & 13 & 64 & No & Yes \\
\hline & Sundos & 45 & Primary & 4 & 13 & 70 & Yes & Yes \\
\hline & Juhaina & 51 & Primary & 4 & 13 & 68 & No & Yes \\
\hline \multirow{6}{*}{$\begin{array}{l}\text { SME1 } \\
\text { Restrictive }\end{array}$} & Hidaya* & 30 & Secondary & 2 & 10 & 75 & No & No \\
\hline & Dalal & 55 & Primary & 5 & 32 & 300 & No & No \\
\hline & Ghalia & 34 & Secondary & 3 & 11 & 80 & Yes & Yes \\
\hline & Maysa* & 39 & Secondary & 4 & 17 & 130 & No & No \\
\hline & Riham* & 36 & Secondary & 4 & 10 & 190 & No & No \\
\hline & Nur* & 38 & Secondary & 3 & 15 & 250 & No & No \\
\hline \multirow{5}{*}{$\begin{array}{l}\text { SME2 } \\
\text { Non- } \\
\text { Restictive }\end{array}$} & Samira & 52 & Secondary & 3 & 22 & 100 & Yes & $\mathrm{n} / \mathrm{a}$ \\
\hline & Malak & 48 & University & 4 & 22 & 130 & No & $\mathrm{n} / \mathrm{a}$ \\
\hline & Ban & 56 & Secondary & 5 & 17 & 110 & Yes & $\mathrm{n} / \mathrm{a}$ \\
\hline & Sadeer & 44 & Secondary & 3 & 19 & 125 & Yes & $\mathrm{n} / \mathrm{a}$ \\
\hline & Makbula & 43 & Secondary & 3 & 23 & 162 & Yes & $\mathrm{n} / \mathrm{a}$ \\
\hline \multirow{5}{*}{$\begin{array}{l}\text { SME3 } \\
\text { Non- } \\
\text { Restrictive }\end{array}$} & Lama & 43 & Primary & 1 & 13 & 80 & No & $\mathrm{n} / \mathrm{a}$ \\
\hline & Amal & 55 & Primary & 6 & 13 & 70 & No & $\mathrm{n} / \mathrm{a}$ \\
\hline & Jiman & 54 & Primary & 5 & 13 & 65 & Yes & $\mathrm{n} / \mathrm{a}$ \\
\hline & Najat & 35 & Primary & 6 & 13 & 62 & Yes & $\mathrm{n} / \mathrm{a}$ \\
\hline & Salma & 31 & Primary & 3 & 13 & 63 & Yes & $\mathrm{n} / \mathrm{a}$ \\
\hline \multirow{5}{*}{$\begin{array}{l}\text { SME 4 } \\
\text { Non- } \\
\text { Restrictive }\end{array}$} & Salha & 34 & Secondary & 4 & 12 & 52 & Yes & $\mathrm{n} / \mathrm{a}$ \\
\hline & Nihaya & 46 & Primary & 6 & 14 & 73 & Yes & $\mathrm{n} / \mathrm{a}$ \\
\hline & Hania & 45 & Primary & 5 & 14 & 70 & Yes & $\mathrm{n} / \mathrm{a}$ \\
\hline & Dara & 30 & Secondary & 2 & 9 & 40 & Yes & $\mathrm{n} / \mathrm{a}$ \\
\hline & Amira & 32 & Secondary & 3 & 11 & 55 & Yes & $\mathrm{n} / \mathrm{a}$ \\
\hline
\end{tabular}

KEY: + divorced, * implicated by others as participating in hidden network. Names in bold represent network leaders. 
Figure 1: The Revealed Relationships within Hidden Networks of Collaborative Production

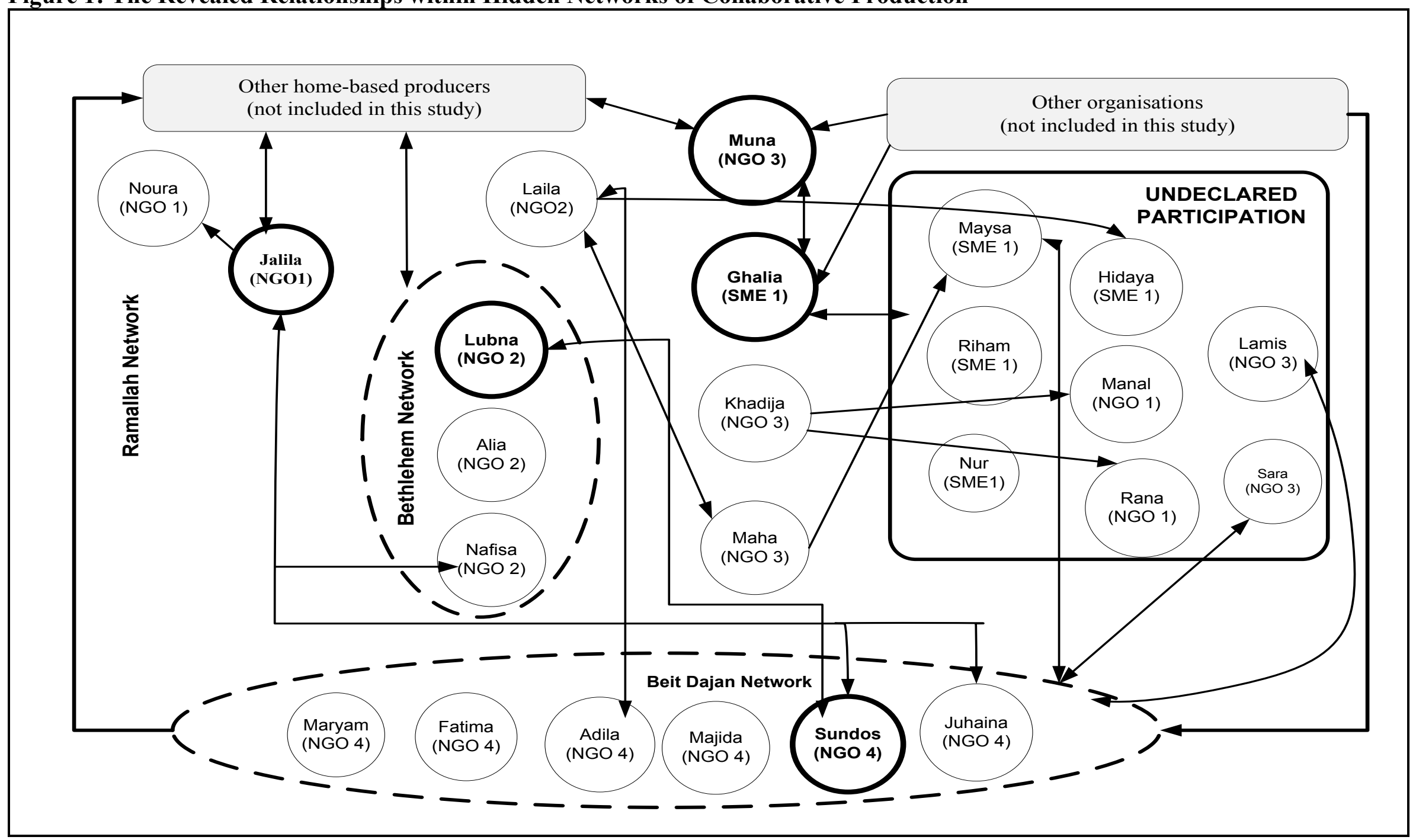

Key: Network Founders: Sub-network: (-ー) 
